Aileen Fyfe, "Tracts, classics and brands: science for children in the nineteenth century" in Popular Children's Literature in Britain, 1700-1900, edited by Julia Briggs, Denis Butts and M. O. G. Grenby

\title{
Tracts, classics and brands: science for children in the nineteenth century ${ }^{1}$
}

\begin{abstract}
Aileen Fyfe
If we are to believe William Thackeray, science books for children were not popular. He claimed that in his younger days, 'Abominable attempts were made... to make useful books for children, and cram science down their throats as calomel used to be administered under the pretence of a spoonful of currant-jelly. ${ }^{2}$ We get a similar impression from Charles Kingsley, writing the preface to his own children's science book twenty-five years later, and remembering that the books he read as a child were 'few and dull, and the pictures in them ugly and mean'. ${ }^{3}$ Nevertheless, Kingsley went on to mention one story, which, even though it was an 'old-fashioned, prim, sententious story', had made an impact on him. ${ }^{4}$ Writer and critic John Ruskin, botanist Jane Loudon, geologist Gideon Mantell and doctor's wife Phoebe Lankester, as well as religious leaders F. D. Maurice and Benjamin Gregory all remembered the same story. ${ }^{5}$ Here, at least, is one story which left a positive impression. It was called 'Eyes and no eyes; or, the art of seeing', and was one of many stories contained in Evenings at Home; or the juvenile budget opened (1792-96).
\end{abstract}

Written by John Aikin and his sister Anna Laetitia Barbauld, Evenings at Home contained a large proportion of conversations and stories about natural history, chemistry and astronomy, alongside moral tales and the occasional poem. 'Eyes and no eyes' was one of Aikin's contributions. ${ }^{6}$ It describes two boys recounting a walk through the countryside. Andrew had been bored stiff, but William had enjoyed the 
Aileen Fyfe, "Tracts, classics and brands: science for children in the nineteenth century" in Popular Children's Literature in Britain, 1700-1900, edited by Julia Briggs, Denis Butts and M. O. G. Grenby

walk and found plenty to interest him in the flora, fauna, people and places that he passed. The moral pointed out by their tutor was to 'learn that eyes were given you to use'. ${ }^{7}$ We can see why this story might be especially remembered by those who, in later life, practised the art of observation, whether as naturalists or art critics. The problem of assessing popularity from the experiences of actual readers of children's books (apart from its scarcity) is that adult recollections may have been coloured by the experiences of the intervening years. Equally, evidence of sales figures is no clear indication of popularity with children, as most sales were made to parents or guardians, whose charges may or may not have read, let alone enjoyed, the books.

Popularity with children, however, is only one aspect of the issue of popular children's books, and in this essay I propose to concentrate on two alternative definitions of popularity. The first is the prevailing early nineteenth-century usage of 'popular', meaning a work which was intended for 'the people', and which would therefore be low in price and high in circulation. ${ }^{8}$ The second concerns what was popular with publishers, rather than with children. For the first definition, I will take the example of the Religious Tract Society (RTS), a publishing organisation dedicated to low prices and high (often very high) circulations. Its evangelical mission to convert the industrial working classes to Christianity meant that - unlike most publishers - it was committed to getting its publications to the people who needed them, and not simply to the first paying customer. Its children's science publications were often not books, but much cheaper sewn pamphlets which would have had circulations far in excess of most books. Due to the RTS's habit of not dating its 
Aileen Fyfe, "Tracts, classics and brands: science for children in the nineteenth century" in Popular Children's Literature in Britain, 1700-1900, edited by Julia Briggs, Denis Butts and M. O. G. Grenby

works, it is very difficult to know how long its works remained in print. We can be sure they sold in high numbers initially, but long-term influence is difficult to gauge. To consider my second definition, of works which were popular with publishers, I will examine two sorts of successful works, those which are kept in print for a long time, and those which are frequently imitated. My examples here will be the 120 -year publishing history of Evenings at Home, and the vogue for books titled 'Conversations on ...' in the 1820 s.

These two approaches to the issue of popular children's books have the advantage of being linked more to publishers than to readers, and thus supply more evidence for the historian. A running theme in this essay will be the question of whether popularity with publishers can ultimately tell us anything about popularity with readers, particularly child readers. Before beginning, however, we need an overview of the state of children's science literature in the first half of the nineteenth century.

By the mid-eighteenth century, the sciences had become part of a 'public culture', entering an increasingly commercialised marketplace in the form of lectures, demonstrations, books and periodicals. ${ }^{9}$ Among the other new commodities were products aimed specifically at children, such as books, games and puzzles. ${ }^{10}$ It was in this context that the first science books which we identify as written specifically for children appeared. The first is usually said to be the pseudonymous Tom Telescope's Newtonian System of Philosophy, adapted to the capacities of young gentlemen and 
Aileen Fyfe, "Tracts, classics and brands: science for children in the nineteenth century" in Popular Children's Literature in Britain, 1700-1900, edited by Julia Briggs, Denis Butts and M. O. G. Grenby

ladies (1761), published and probably written by John Newbery, the man generally credited with the creation of the children's book genre in the $1740 \mathrm{~s} .{ }^{11}$ In the Newtonian System, a group of budding young natural philosophers, the Lilliputian Society, attend lectures and demonstrations delivered by a youthful 'Tom Telescope'. Many of the features which would become typical of children's non-fiction for the next seventy years were already present: the inclusion of moral lessons alongside the natural philosophy; the recourse to easy-to-understand examples from everyday life; and the use of a conversational format, in which the information is conveyed as a dialogue between two or more characters, with only limited narration to set the scene.

The combination of instruction and amusement blossomed in the late eighteenth century, and the sciences were regarded as particularly good subject matter. ${ }^{12}$ The works were expected to appeal to young children's innate curiosity about the natural world, and it was not too difficult for writers to move from nature to its Creator, thus introducing the almost compulsory moral lesson. In the first decades of the nineteenth century, a myriad of 'conversations', 'dialogues', 'letters' and 'catechisms' flowed from the publishers' houses. Jeremiah Joyce's Scientific Dialogues (1800-05) claimed to follow on from Evenings at Home, and covered a range of the sciences, but most of the works were more restricted in subject matter. Samuel Parkes and Jane Marcet, for instance, both focussed on chemistry, with his Chemical Catechism (1806) and her Conversations on Chemistry (1806). Marcet was just one of the many women to whom the conversation genre appealed. The frequent 
Aileen Fyfe, "Tracts, classics and brands: science for children in the nineteenth century" in Popular Children's Literature in Britain, 1700-1900, edited by Julia Briggs, Denis Butts and M. O. G. Grenby

representation of girls learning from women within the books could help legitimate the authority of the female writer on the sciences. ${ }^{13}$

The regular publication of children's science books by the early nineteenth century indicates that the sciences were not merely acceptable in the nursery, but had become a standard part of childhood. Some form of natural history was particularly common, as discussions of plants or animals could be easily related to everyday life. Astronomy was another favourite, but subjects like natural philosophy or chemistry, which dealt with less tangible concepts, tended to be for older children. Around thirty or forty children's science books were being published each decade at the beginning of the century, and by the middle of the century, that had risen to around ninety books per decade. ${ }^{14}$ There was clearly a growing market for such works, and middle-class parents were being offered an ever-increasing range of books to choose from. The now-traditional 'instructive and amusing' style dominated in the first half of the century, although alternatives were beginning to emerge by mid-century.

Fictional conversations such as Marcet's or Aikin and Barbuald's were supposed to mimic the real conversations that ideal parents would have with their children. Conversation was widely regarded as good way for a young child to learn, even about complicated subjects. As Richard and Maria Edgeworth had put it in their Practical Education (1797), 'We have found, from experience, that an early knowledge of the first principles of science may be given in conversation, and may be insensibly acquired from the usual incidents of life' ${ }^{15}$ Reading fictional conversations mimicked the experience of a real conversation, allowing the child-reader to learn 
Aileen Fyfe, "Tracts, classics and brands: science for children in the nineteenth century" in Popular Children's Literature in Britain, 1700-1900, edited by Julia Briggs, Denis Butts and M. O. G. Grenby

alongside the fictional child. It was generally accepted that children learned more effectively when they were interested in the subject. Again, conversations were a useful form because they allowed authors to write their works as drama, with action either implied from the dialogue, or described in accompanying narrative. Instruction was thus conveyed within a story, which helped to make learning fun.

In contrast to other non-fiction writers, science writers had some advantages when trying to be entertaining. Children's curiosity about the things they could see around them provided an obvious starting point. At its most basic, this could mean paying close attention to the behaviour of toys in the nursery, such as the spinning top used in Tom Telescope's Newtonian System. Similarly, John Ayrton Paris's Philosophy in Sport made Science in Earnest (1827) used childhood toys and games to teach natural philosophy. Indeed, by the 1840 s, a whole genre developed of the 'science of common things' or 'things familiar', including Charles Williams's Philosophy of Common Things (c.1845) and Ebeneezer Cobham Brewer's The Scientific Knowledge of Things Familiar (1847). ${ }^{16}$ The latter was reputed to have sold 160,000 copies by $1874 .{ }^{17}$ The sciences also offered opportunities for practical activities. Fictional children were frequently going places, collecting things, or trying simple experiments, which might inspire readers at home. For natural history, this might mean a walk in the garden or the nearby fields, observing the local wildlife or collecting plants, as the tutor frequently recommends Harry and George to do in Aikin and Barbauld's Evenings at Home. Astronomical knowledge could be imparted by looking at the stars, as Henry and his father do while walking home at the beginning 
Aileen Fyfe, "Tracts, classics and brands: science for children in the nineteenth century" in Popular Children's Literature in Britain, 1700-1900, edited by Julia Briggs, Denis Butts and M. O. G. Grenby

of Sarah Tomlinson's Starry Heavens (undated, 1847), which formed the first part of the 'First Steps in General Knowledge' series issued by the Society for Promoting Christian Knowledge. Readers of Evenings at Home might even have been tempted to try the simple experiments with oyster shells and vinegar discussed by George and his tutor during a conversation on chemistry. ${ }^{18}$ Learning through practical involvement would be even more effective (because interesting and exciting) than learning from a book. Although Greg Myers has noted the irony of books which encourage learning through practical activities while themselves imparting knowledge through the printed word, some writers did make strenuous efforts to encourage their readers to really go and do things, rather than simply read. ${ }^{19}$

The general trend in children's literature towards more realistic representations of children, and more complex modes of narration, also appeared in science books. ${ }^{20}$ Children in instructive conversations had been routinely given adult voices, and forced to behave in a way that suited the narrator's proposed scheme of instruction. Thus, the wording of their questions sounded unlikely, while the topic of their questions appeared suspiciously suitable for their adult interlocutors' next point. For example, twelve-year old Cecilia, in Priscilla Wakefield's Mental Improvement (1794-97), commented: 'I observed you named sponge among the zoophytes; surely that cannot be the habitation of insects. I have often wondered what it is, but have never been able to satisfy my curiosity. ${ }^{21}$ This tendency was exacerbated by the relatively small amount of surrounding narration in which most early nineteenthcentury conversations were set, as the reader's impression of the characters had to be 
Aileen Fyfe, "Tracts, classics and brands: science for children in the nineteenth century" in Popular Children's Literature in Britain, 1700-1900, edited by Julia Briggs, Denis Butts and M. O. G. Grenby

gained almost entirely from their speeches. By the middle of the nineteenth century, authors who continued to use the conversational form strove to make their children seem more realistic. A good example of this can be seen in Eliza W. Payne's Peeps at Nature: or, God's Works and Man's Wants (1850), which will be discussed in more detail later. Alexander is full of ideas and questions that sound like they actually came from a child, rather than a parent. By mid-century, however, third-person narrative was beginning to overtake conversation as the dominant style for children's science books. Early efforts tried to create a sense of excitement by focusing on wonders and marvels, perhaps even using the conceit in their titles, as in Samuel Clark's Peter Parley's Wonders of Earth, Sea and Sky (undated, 1837), or Charles Williams's Wonders of the Waters (undated, 1842). The narrators of such works were often given a strong persona as the favourite, well-travelled and knowledgeable uncle. Thus, although no longer written as conversations, they still mimicked the form of oral storytelling.

One thing which did not change through the first half of the nineteenth century was that it remained utterly standard for children's authors to present the sciences as the study of God's creation. The study of nature could encourage feelings of awe and devotion in young children, and could help to make real the God of Scripture. For some authors, particularly in the late eighteenth and early nineteenth centuries, this religious utility seemed to be the main justification for writing about the sciences, as is suggested by the title of Sarah Trimmer's An Easy Introduction to the Knowledge of Nature and Reading the Holy Scriptures (1780). ${ }^{22}$ A clear religious framework was 
Aileen Fyfe, "Tracts, classics and brands: science for children in the nineteenth century" in Popular Children's Literature in Britain, 1700-1900, edited by Julia Briggs, Denis Butts and M. O. G. Grenby

particularly crucial in the turbulent decades after the French Revolution. Secular, let alone atheistic, science had revolutionary overtones, and the radical associations were continued into the 1830 s by working-class champions of political change who found support for their arguments in French scientific theories. ${ }^{23}$ French chemistry, transmutation, or celestial physics were therefore not the sorts of things which would be found in British children's books, and even the absence of explicit religion could raise suspicions. Supposedly the most delicate members of society, children had to be carefully protected from dangerous ideas. Although books on the sciences for adults written in a secular manner began to be available from the 1840 s, it was much later in the century before that became possible for children's books.

When mid-nineteenth-century commentators talked about 'popular literature' they usually meant literature which was widely read outside the typical educated middleclass book-reading circles. It might mean literature which was cheap enough for at least some of the working classes, or it might additionally mean literature which was generally acceptable and liked by them. ${ }^{24}$ This no longer meant just chapbooks and ballads, but included the products of steam-powered printing, from penny periodicals to railway novels. ${ }^{25}$ The place of children's books in such discussions of the popular is ambiguous, since children's books were generally much cheaper than their adult counterparts. Each volume of Evenings at Home cost just one shilling and sixpence because they were small duodecimos, and only 150 pages long. A typical adult volume at the time would have been about 300 pages octavo, and would have cost 
Aileen Fyfe, "Tracts, classics and brands: science for children in the nineteenth century" in Popular Children's Literature in Britain, 1700-1900, edited by Julia Briggs, Denis Butts and M. O. G. Grenby

around 10 shillings. This meant that science books intended for middle-class children might have appealed to working-class adults in the first half of the century, because of their low cost and simple language at a time when there was only a limited range of popular science books for adults. However, many of the canonical children's science books were not really that cheap. Evenings at Home ran to six volumes, and the complete work was being sold for ten shillings and sixpence in the 1820s. Similarly, Marcet's Conversations cost fourteen shillings, and Joyce's Dialogues fifteen shillings. ${ }^{26}$ These prices made them solidly middle-class books.

The Religious Tract Society, on the other hand, issued works on the sciences ranging in price from two shillings down to a farthing. ${ }^{27}$ Its cheapest publications took the same form as its tracts, being unbound, and only 16 or 32 pages long. This format was printed in tens of thousands, at low unit price, either for individual sale or bulk distribution. The Society's 1850 catalogue of children's books makes clear the variety of works it produced. ${ }^{28}$ There were several series of short tracts specifically for children learning to read, and the authors of these sometimes took natural history as their theme. The 'New Series of Children's books, easy words and large print, 32mo with engravings' launched in 1845 included farthing tracts on The Wren's Nest by Mrs Wright of Croydon and The Eagle's Nest by J. B. Maynard, Esq., of Holmewood near Ryde, as well as Esther Copley (1786-1851) on The Acorn and George Mogridge (1787-1854) on The Bamboo, for one penny each. All four of these writers were RTS regulars, and none specialised in writing on the sciences. The ephemeral nature of works like these makes them difficult to locate in academic libraries, but it is probable 
Aileen Fyfe, "Tracts, classics and brands: science for children in the nineteenth century" in Popular Children's Literature in Britain, 1700-1900, edited by Julia Briggs, Denis Butts and M. O. G. Grenby

that these works used the natural world as a setting for their story (with its religious moral), rather than specifically trying to convey instruction about nature. That a wide audience was intended is indicated by the note in the catalogue which claims these would all be suitable for 'Sunday, national, British and common day schools' as well as 'families and boarding schools'. Although these particular tracts were priced individually, it was common for the Society to price tracts, including children's tracts, by the hundred. The series which had preceded this 'New Series' had included a History of Beasts costing two shillings and eight pence per hundred (equivalent to a third of a penny each). This method of pricing encouraged philanthropically-minded members of the Society to buy in bulk, and give the tracts away to local school children. In this way, RTS children's works probably reached a far wider audience than most of the other books in this essay.

The works intended for older children had a greater scientific content, although it varied with the expected age and social class of the audience. The RTS editor, the Rev. Charles Williams (1796-1866), wrote seven 'Penny Books on Natural Objects' in 1845-46. These were tiny 32-page tracts, discussing topics such as the nettle, the rose-leaf, the cherry and the hazel-nut, with an illustration of the relevant plant on the first page (that is to say, the cover). These were written as conversations between 'Uncle William' and his young friends, with narrative to set the scene. Thus, the discussion of hazel-nuts appears in the context of a 'nutting' expedition, while another tract opens with Uncle William meeting a boy who has been stung by a nettle. Uncle William applies the necessary dock leaf, and tries to convince the sceptical 
Aileen Fyfe, "Tracts, classics and brands: science for children in the nineteenth century" in Popular Children's Literature in Britain, 1700-1900, edited by Julia Briggs, Denis Butts and M. O. G. Grenby

Henry that nettles really are fascinating. ${ }^{29}$ Five of these tracts were re-issued as a sixpenny volume in 1846 under the title Uncle William's Talkings with Children about Plants, with gilt edging, and an orange paper cover.

Williams also wrote a series of four-penny 'square books' for slightly older children, again focussing on natural history. As before, these initially appeared as tracts before being collected into groups of five. This time, the volume was bound in cloth boards with gilt decoration, and had been given a new, illustrated, title-page. There were at least seven of these two-shilling volumes, including Remarkable Insects (1842), Wonders of the Waters (1842) and The Face of the Earth (1846). Unlike Talkings, they were not written as conversations, but used continuous third-person narrative. In an effort to keep his reader's interest, the narrator made a point of stressing the wonders of creatures from star-fish to electric eels. This also allowed him easily to introduce devotional thoughts on the objects of Creation. Even the lobster, which has rarely 'awakened the admiration which it ought to call forth..., shows as clearly that God made it, as any creature that can be taken from the surface of the earth, or from the midst of the waters' ${ }^{30}$ All RTS works had a devotional cast, but they also had to have a statement of the route to salvation through faith in the atonement, which was more difficult to introduce. In Wonders of the Waters, it appeared in the chapter on the fish, when the narrator introduced the Redemption by reminding his readers that, 'In thus referring to the provision made for inferior creatures, it is of great importance that the mind should dwell also on the provision made for ourselves' ${ }^{31}$ 
Aileen Fyfe, "Tracts, classics and brands: science for children in the nineteenth century" in Popular Children's Literature in Britain, 1700-1900, edited by Julia Briggs, Denis Butts and M. O. G. Grenby

Williams was dismissed as RTS editor in 1849 , for spending too much time on his authorship, instead of overseeing the running of the Society's publishing operations. There was also concern that he had not subjected his own books to the usual reports of readers before publication. ${ }^{32}$ Assuming they stayed within approved limits, however, it was quite usual for the Society's editors to engage in authorship, and the new children's editor, John Henry Cross, certainly did so. ${ }^{33}$ Unlike Williams, he did not write on the sciences very often, but he did write the letterpress for $A$ Book about Animals (1852, two shillings). The showpiece of this book was the six Kronheim colour plates to which the large-print text provided commentary. Although some of the animals, such as the elephant, were not stunningly realistic representations, the very presence of colour plates would have been eye-catching enough. The book was bound in white cloth, embellished with blue and pink ink, and gilt, producing something far more elaborate than the Society's usual self-coloured paper with black printing, or drab cloth boards with just a hint of gilt. This work and its predecessor, Mrs Wright's A Book about Birds (1850), must be among the earliest fruits of the Society's connection with Kronheim. ${ }^{34}$

A Book about Animals was clearly not intended for children at National or Sunday schools. For different reasons, the same was true of the Society's more advanced books on the sciences. Most of those which appeared as books (rather than tracts) were more expensive - several shillings, instead of several pennies - and tended to use more complicated language. One of the many women writers who were first published with the RTS was Eliza W. Payne, of Plymouth and later Edgbaston. 
Aileen Fyfe, "Tracts, classics and brands: science for children in the nineteenth century" in Popular Children's Literature in Britain, 1700-1900, edited by Julia Briggs, Denis Butts and M. O. G. Grenby

The fact that her husband, Alfred, was a technical chemist may explain her decision to write on the sciences. ${ }^{35}$ Her first attempts were published as penny and threehalfpenny tracts from 1848, beginning with 'How are People Kept on the Earth? or, The Law of Attraction' and 'The Invisible Fluid; or, Our Own Atmosphere'. Unlike works which described the wonders of the natural world, Payne's works described less visible scientific concepts, such as gravity, the atmosphere and the causes of tides and rainbows. The Society's catalogue suggested that these works would be suitable only for 'families and boarding schools', indicating the need for a higher level of education than could be found in Sunday scholars, and perhaps also the need for educated parents to explain the difficult parts. Payne's fourteen tracts were issued in a bound volume as Peeps at Nature: or, God's Works and Man's Wants (1850, one shilling and sixpence), and her subsequent works for the Society went straight into book format, including Nature's Wonders; or, God's Care over all his Works (1850, two shillings) and Village Science; or, The Laws of Nature Explained (1851, two shillings).

Despite, or perhaps because of, the more complicated nature of her subjects, Payne made particular efforts to ensure that the conversations between Alexander and his mamma were lively. It is tempting to imagine that they were based on her own conversations with her eldest sons, but (unless they were astonishingly precocious) it is unlikely. The real Alexander was about four years old when she was writing her first tracts, and his brother Richard was only a year older. The Alexander of the book seems to be a few years older than his namesake. Nonetheless, her experience with 
Aileen Fyfe, "Tracts, classics and brands: science for children in the nineteenth century" in Popular Children's Literature in Britain, 1700-1900, edited by Julia Briggs, Denis Butts and M. O. G. Grenby

very young children might have inspired her declaration, in the preface to Peeps at Nature, that she would try to follow, 'the actual workings of a child's mind' ${ }^{36}$ And indeed, in the book, Alexander not only asks child-like questions, but his questions dart around and go off at tangents in a manner most unlike the early nineteenthcentury conversations. In the third chapter, on gravitation, Alexander has been thinking over an earlier conversation in which he learned that the earth was spinning. There is 'one thing that has puzzled me very much, mamma... How is it that we do not fall off when it is our turn to be upside down as it were?'. Mamma explains that God has provided an attractive force that keeps people on the earth. Whereas some fictional children would then have urged their parent to tell them more about this attractive force, Alexander asks, 'Is this the reason that a fly can walk on the under side of my book as well as on the top?' Mamma then has to explain about the 'sticky sponges' on the feet of insects before she can continue with the story of gravity. ${ }^{37}$ There are more interruptions and tangents, as Alexander connects what she is telling him to things he already knows, and tries to come up with his own explanations of how things work. This mode of writing means that the instructive element is much less logical and ordered than in other books, but it makes Alexander seem more like a real child, and hopefully more sympathetic, and interesting, to a child-reader.

Unfortunately, the RTS archives do not give any details about the print runs (or sales) of these works. The Society's Jubilee Memorial did give best-seller lists for children's works up to 1850 , but the books discussed here were all too recent to be able to compete with the cumulative sales of older works. Most of the works listed 
Aileen Fyfe, "Tracts, classics and brands: science for children in the nineteenth century" in Popular Children's Literature in Britain, 1700-1900, edited by Julia Briggs, Denis Butts and M. O. G. Grenby

had been published in the early 1830s: six had sold more than 100,000, and nine more had sold over 25,000. Compared with the Society's adult tracts, these were relatively small figures (successful adult tracts of similar age had sold 200,000 or 300,000 copies), but compared with the runs of most books at the time, the numbers are impressive. ${ }^{38}$ Books such as Payne's Village Science or the Book about Animals would not have reached such high circulations, but the works which appeared first in tract format would certainly have been printed in several thousands, because that was how the Society operated. Few other works of science for children were as cheap as these farthing and penny tracts, and few others can have had (at least the potential for) such a wide readership.

I now want to move on to some better-known children's science books, and to ask what we know about their popularity. For most books, all we have to go on is sales figures, if publishers' archives survive, or, more likely, numbers of editions. I want to consider two different sorts of successful book. 'Classic' books are those which continue to be reprinted (and, we assume, read) over a prolonged period of time. They are books which continue to speak to later generations, and in which later readers can find something of relevance to their lives. ${ }^{39}$ They may or may not have been bestsellers at the time of their initial publication. ${ }^{40}$ My other sort of books is those that form 'brands', by which I mean groups of books which share many features, and trade on each other's success. A very few might legitimately be called brands in the full modern sense, such as Pinnock's Catechisms, whose contents were controlled by 
Aileen Fyfe, "Tracts, classics and brands: science for children in the nineteenth century" in Popular Children's Literature in Britain, 1700-1900, edited by Julia Briggs, Denis Butts and M. O. G. Grenby

William Pinnock, but most were less formal groupings, such as the Peter Parley phenomenon. With these, membership was less controlled, but there was still the possibility of trading off other members' successes. ${ }^{41}$

One of the best examples of a classic children's science book is Aikin and Barbauld's Evenings at Home (1792-96). Its six volumes of natural history, moral stories, poems, and conversations on chemistry remained in print until 1915, and until the 1880 s, was being regularly reprinted by several different publishers. By that time, its status as a classic helped to ensure its continued sales, but we need to consider how it became so established. Its initial reception gave little indication that it would have such a long and successful career. Critics were divided on its merits because of the problematic absence of religion. In contrast to most children's writers of the $1780 \mathrm{~s}$ and 1790s, Aikin and Barbauld did not regard religion as the main reason for writing about the sciences. They believed that the sciences were becoming such an important part of industrialising British culture that a child could not grow up to be a responsible member of society without a basic understanding of the natural (and social) world. For them, the sciences were useful subjects in their own right, not just as handmaidens to religion. Furthermore, as Unitarians, they disapproved of sectarianism, and kept their religious references to a minimum to avoid pressing one particular view upon their readers. As a consequence, critics who shared Aikin and Barbauld's viewpoint Maria Edgeworth, for example - were enthusiastic about the work, while those who regarded religion as crucial were more damning. ${ }^{42}$ Anglican and self-appointed guardian of education, Sarah Trimmer recommended that children should only read it 
Aileen Fyfe, "Tracts, classics and brands: science for children in the nineteenth century" in Popular Children's Literature in Britain, 1700-1900, edited by Julia Briggs, Denis Butts and M. O. G. Grenby

'under the care of a judicious parent, or teacher', for if they were left to read it on their own, 'to ruminate upon all its contents, without discrimination, it may prove very injurious'. ${ }^{43}$ Unsurprisingly, most of the evidence for actual readings of Evenings at Home in its first twenty years is from liberal nonconformist families. ${ }^{44}$

This restricted audience did not augur well for long-term success, but publisher Joseph Johnson (also a Unitarian) had issued ten editions by 1814, indicating steady sales. And by the 1810 s, there is evidence that it was beginning to be read more widely, including children from Anglican and Methodist families. Its volumes came out of copyright between 1820-24, and the publisher (now a group of share-holders) produced a revised edition, thus renewing the copyright protection. ${ }^{45}$ Not only were 10,000 copies of the revised edition printed in the 1820 s and 1830 s, but other publishers (usually provincial publishers, such as William Milner of Halifax, and Robert Griffin of Glasgow) began to reprint the original text. ${ }^{46}$ This interest from publishers suggests that it was no longer regarded as a specifically Unitarian book, but had broader appeal.

Yet, by the 1840 s, it seemed to be declining in popularity. The shareholders' print runs were getting smaller, and the 3,000 copies printed in 1836 had not sold out by 1846 . Longman were selling only around thirty copies a year. ${ }^{47}$ Its demise at this point would have been in keeping with the history of other books of a similar age. Tom Telescope's last edition had been in 1838, while Marcet's Conversations on Chemistry had its final edition in 1853. Incredibly, Evenings at Home survived, and went on to sell far more copies in the second half of the nineteenth century than it had 
Aileen Fyfe, "Tracts, classics and brands: science for children in the nineteenth century" in Popular Children's Literature in Britain, 1700-1900, edited by Julia Briggs, Denis Butts and M. O. G. Grenby

done in the first. ${ }^{48}$ This was due to the intervention of George Routledge, and demonstrates the active role of publishers, not merely in responding to, but in shaping public demand. Evenings at Home had been a respected, but out-of-date work. Routledge established it as a classic, which deserved to be on every list of gift or reward books, and in so doing, he revived its fortunes for another fifty years.

As an entrepreneurial newcomer to the publishing trade, Routledge was looking for a quick way to make money. He made his name by producing cheap editions of out-of-copyright works, perhaps most famously with his 'Railway Library' of shilling volumes, from $1848 .{ }^{49}$ His two main sources were old British works and American works, neither of which were protected by British copyright law. Evenings at Home appeared on page one of the Publication Book for 1851, the year in which Routledge and Co. was founded. Thomas Day's Sandford and Merton (1783-89) was on page two, followed by Swiss Family Robinson (1814). ${ }^{50}$ For Evenings at Home, Routledge commissioned a new set of revisions. Although they were less meticulous than the 1820 s revisions, Routledge was able to claim copyright protection for what appeared to be the most up-to-date edition on the market. ${ }^{51}$ The share-holders' editions had been selling at ten shillings and sixpence, although leftover copies were reduced to five shillings in $1846 .{ }^{52}$ In contrast, Routledge brought out his copies at three shillings and sixpence, and printed runs of 2,000 every two or three years. In 1866 , he was printing runs of 4,000 copies of a one shilling and sixpence edition. The share-holders printed just 3,000 copies in the 1850s, compared to Routledge's 10,000 in the same decade ${ }^{53}$ Routledge clearly showed that by publishing the work more 
Aileen Fyfe, "Tracts, classics and brands: science for children in the nineteenth century" in Popular Children's Literature in Britain, 1700-1900, edited by Julia Briggs, Denis Butts and M. O. G. Grenby

cheaply, he could sell far more copies of it. By 1900, he had sold a stunning 59,000 copies. ${ }^{54}$ Furthermore, competing publishers (including Ward, Lock and Co. and Routledge's brother-in-law, Frederick Warne) also jumped on the bandwagon, issuing at least fourteen reprint editions of the old, unrevised text. As well as issuing it in cheap editions, these publishers presented it as a reward book, in decorative covers, and added colour plates to the wood-engravings which had been standard since the 1840s. ${ }^{55}$ In this format, it became the reliable and well-loved classic which every child should own.

Publishers like classics because their past success holds out the promise of continued sales into the future. During the period of copyright protection, however, only one publisher is entitled to reprint a successful work. Other publishers could attempt to cash in on its success either by waiting for the end of copyright, or by issuing imitations. If there was a particular style, format or subject matter which seemed particularly successful, publishers could hope that it would be again. I now want to look at this issue of imitation, which tells us about the success of a work as judged by contemporary publishers and writers. The most commonly-imitated form for children's science books in the early nineteenth century was a variation on the conversation or the dialogue. Late eighteenth-century books had used the style (including Tom Telescope, and Evenings at Home) but if the word 'conversation' appeared in the title, it did so in the depths of the subtitle, as in Priscilla Wakefield's Mental Improvement; or, the beauties and wonders of nature and art, in a series of instructive conversations (1797). ${ }^{56}$ 
Aileen Fyfe, "Tracts, classics and brands: science for children in the nineteenth century" in Popular Children's Literature in Britain, 1700-1900, edited by Julia Briggs, Denis Butts and M. O. G. Grenby

In the early nineteenth century, works which used 'conversations' prominently in their titles were usually manuals for learning a foreign language, or religious tracts. ${ }^{57}$ However, two books on the sciences used the style: Charlotte Smith's Conversations introducing poetry, chiefly on subjects of natural history (1804), and Jane Marcet's Conversations on Chemistry (1806). There followed a great enthusiasm for science books called 'Conversations on...', which had its heyday in the 1820 s, when (on average) two science books with such titles were published each year. The more successful of these were reprinted throughout the 1830s, but the trend was in decline by the 1840s. By the 1860s, only two science books called themselves 'Conversations'.

Marcet is frequently placed in the canon of children's science books, not least because of her influence on Michael Faraday, and there is an implicit claim that her Conversations on Chemistry was the originator of the subsequent flood of 'Conversations on... ${ }^{58}$ However, there is a problem. The boom in 'Conversations on' actually began in the late 1810 s, and was at its peak in the 1820 s. It included Sarah and Elizabeth Fitton's Conversations on Botany (1817), William Cole's Conversations on Algebra (1818), Marcet's Conversations on Natural Philosophy (1819), Delvalle Lowry's Conversations on Mineralogy (1822), the Astronomical Conversations for Children (1822) by 'Cantabrigiensis', the anonymous Conversations on Geology (1828), and Marcet's Conversations on Vegetable Physiology (1829). Conversations on Chemistry itself benefited from the boom, selling (on average) just over 600 copies a year in the 1820 s, compared with around 
Aileen Fyfe, "Tracts, classics and brands: science for children in the nineteenth century" in Popular Children's Literature in Britain, 1700-1900, edited by Julia Briggs, Denis Butts and M. O. G. Grenby

490 copies a year in the 1810 s. ${ }^{59}$ If Marcet deserves the credit, her Conversations on Political Economy (1816) would be a more convincing contender. ${ }^{60}$

'Conversations on...' were not the only popular brands of the 1820 s, as titles using 'Dialogues' and 'Catechisms' were also common ('catechism' more so, 'dialogue' less so). The 'dialogue' may well have originated with Joyce’s Scientific Dialogues, but the enthusiasm for 'catechisms' cannot be ascribed to Parke's Chemical Catechism. Rather, William Pinnock's series of catechisms accounts for the majority of all the catechisms published in this period. Like 'dialogues' and 'conversations', the 'catechism' had almost died out by mid-century, though it left traces in other forms, such as Brewer's catechetical Guide to the Scientific Knowledge of Things Familiar.

The existence of 'brands' such as these do not mean that every publication of the sort was a great success, but it strongly suggests that many of them (particularly the earlier ones) were. Other authors hoped that their works would be successful if framed in the same way, and publishers must have hoped so too, given their willingness to publish so many of them. Of the group of 'Conversations on...' mentioned above, the most reprinted works were Fitton's Conversations on Botany, and Marcet's works on chemistry and natural philosophy. By 1840, the botany and natural philosophy had reached their ninth editions, while chemistry was on its thirteenth. These were all published by Longman and Co., as was Lowry's Conversations on Mineralogy and Marcet's other five books of 'Conversations'. Indeed, Longman was the dominant publisher of 'Conversations on...' in the 1820s, 
Aileen Fyfe, "Tracts, classics and brands: science for children in the nineteenth century" in Popular Children's Literature in Britain, 1700-1900, edited by Julia Briggs, Denis Butts and M. O. G. Grenby

also using the style for subjects such as Christianity (1826), mythology (1827), the English Constitution (1828) and chronology and history (1830). ${ }^{61}$

Longman printed a thousand copies of Conversations on Chemistry, in December 1805. By the third (1809) edition, the runs were increased to 1,500 copies, and there were even two editions of 2,000 copies in the 1820 s. By 1840 , it had sold 18,000 copies. Marcet had a half profits agreement, and received her first payment of $£ 92.3 \mathrm{~s} .11 \frac{1}{2} \mathrm{~d}$ in March 1807. By 1840, she had received just over $£ 2,000$ from Conversations on Chemistry, as, of course, had Longman. The conversations on natural philosophy and botany appear to have similar publishing histories and finances, which makes it clear why Longman became so keen on the format in the mid-1820s. By the late 1820s, however, it was beginning to run out of steam. Longman printed 1,000 copies of Conversations upon Chronology and History by Jane Webb (later Loudon) in 1830, but remaindered the last 353 copies in 1836, leaving the work with a loss of $£ 36$. Just over 300 copies of the Conversations on Animal Economy, by a physician (1827) were also remaindered in 1836, but it had at least been in profit (just) since $1830 .{ }^{62}$ Marcet's name on the title-page clearly helped, and her Conversations on Vegetable Physiology (1829) managed to sell three editions, but even Marcet was beginning to move away from the format, and was increasingly writing books specifically for young children.

So far, we have considered books which were popular with publishers, but we also need to examine what, if anything, this tell us about their readers. Sales of children's books are not an obvious indication of popularity among readers, since 
Aileen Fyfe, "Tracts, classics and brands: science for children in the nineteenth century" in Popular Children's Literature in Britain, 1700-1900, edited by Julia Briggs, Denis Butts and M. O. G. Grenby

most children's books are bought by parents or guardians. Continuing sales of children's books does not tell us whether children would have chosen to read those books. However, it does tell us that certain adults chose the books (admittedly, from the selection offered by publishers), and wanted their children to read them. Presumably, the adults must have acquired a positive impression of the book, whether from reviews, from personal recommendations, or from memories of their own childhood reading. Continuing sales of a classic children's books in the 1870s might indicate, not popularity with 1870 s children, but popularity with 1840 s children.

Thus the decline in sales of Evenings at Home in the 1880s and 1890s could indicate a decline in favour among children thirty years earlier, when the book-buying parents of the 1880s and 1890s were child readers themselves. Their subsequent unwillingness to buy Evenings at Home for their own children suggests that it had not made such a strong impression on them as it had on their parents. Given the developments in children's books that were happening by this time, this is hardly surprising. By the 1850s, there were more children's science books available, they looked more attractive, they were more precisely targeted at their readers, and they made greater efforts to be entertaining. Even in a recently revised edition, a work like Evenings at Home was up against stiff competition. By the time the children of the 1850s had children of their own, this was even more true, and any adult who was aware of the rapid contemporary developments in the sciences would have realised that a 1790s book would now be extremely old-fashioned. This suggests that Routledge's success with Evenings at Home in the 1850s and 1860s was assisted by 
Aileen Fyfe, "Tracts, classics and brands: science for children in the nineteenth century" in Popular Children's Literature in Britain, 1700-1900, edited by Julia Briggs, Denis Butts and M. O. G. Grenby

parents' fond memories from the 1820 s and 1830s outweighing the temptations of newer books (and not just his lower prices). ${ }^{63}$

Few other children's science books lasted as long as Evenings at Home. Joyce's Scientific Dialogues were in print for at least sixty-eight years. ${ }^{64}$ Marcet's Conversations on Chemistry remained in print for forty-seven years, and her Conversations on Natural Philosophy for thirty-nine years. Arabella Buckley's Fairyland of Science (1879) is usually regarded as a late nineteenth-century classic, but it too managed just forty years. It was increasingly difficult for any children's science book published in the second half of the century to achieve long-running sales, due to the growing competition and the rapid pace of change in the sciences. This final section considers the changes which affected children's science books in the later nineteenth century, and the extent to which they were related to broader changes happening in children's literature in general.

Among the most obvious of the later developments were the new techniques for decorative bindings and colour printing. Like all children's books, science books benefited from a more attractive appearance. ${ }^{65}$ It is less clear whether such improvements affected the instructional quality of science books, partly because line diagrams could already be adequately reproduced using wood-engravings, but more importantly because colour plates were still expensive enough to be used sparingly, and thus tended to be decorative extras, rather than crucial explanations. Routledge's reward-book editions of Evenings at Home had colour plates, but they were used to 
Aileen Fyfe, "Tracts, classics and brands: science for children in the nineteenth century" in Popular Children's Literature in Britain, 1700-1900, edited by Julia Briggs, Denis Butts and M. O. G. Grenby

illustrate the activities of the characters in the conversation, not, for example, to elucidate the characteristics of the particular flower under discussion.

The heyday of the conversational format was over by mid-century. It was still used occasionally, as in Agnes Giberne's Among the Stars (1885), but it was accompanied by a much more convincing fictional story. Third-person narrative had become the standard, but the avuncular narrator, who recounted all the wonders he had seen in Peter Parley style, was also passé. Writers still had to deal with the issue of creating excitement and staving off boredom, and one possible solution can be seen in Buckley's conceit of explaining the laws of nature in the language of fairies in her Fairy-land of Science (1879), an enterprise which indicates the imaginative effort that was being put into ensuring that instruction was entertaining. Equally, John Henry Pepper's emphasis on exciting experiments in his Boy's Playbook of Science (1860) was an effort to keep his readers interested, as well as continuing the old emphasis on learning through practical involvement. His book included experiments with household objects such as glass jars or umbrellas to explain basic principles of science. Admittedly, it also included plenty of experiments which would have been more difficult to carry out in the home, but the emphasis on learning through doing was clear.

Children's books became more differentiated in the late nineteenth century, and this happened to science books as well. The majority were still intended for the children of middle-class families, for such families had disposable income to spend on their children, and the children had the literacy, educational background and leisure 
Aileen Fyfe, "Tracts, classics and brands: science for children in the nineteenth century" in Popular Children's Literature in Britain, 1700-1900, edited by Julia Briggs, Denis Butts and M. O. G. Grenby

time to read such books. However, there was greater differentiation by age, particularly from mid-century onwards, with writers producing books with differing levels of language skills, technical difficulty, and, not least importantly, numbers of pages. Evenings at Home had been aimed at seven to ten year-olds, but its language would seem advanced for a modern ten year-old. Pepper's Boy's Playbook was clearly aimed at teenagers, while the RTS continued to produce works for those just learning to read. The majority of early children's science books seem to have been aimed at readers of both sexes, but Pepper's title makes clear that he was aiming at a male audience, as did the Rev. John George Wood with his Boy's Own Book of Natural History (1861). This is in keeping with the increased gendering of children's literature in general with its different school stories for girls and boys, as well as family stories for girls and adventure stories for boys. Yet, there were few girls' books of science, which is presumably a reflection of the increasingly masculine image of contemporary experimental science.

A particular problem for children's science writers was that the language of science was becoming increasingly complex by the second half of the century. This was the problem which Buckley's fairies were intended to solve. The various disciplines were becoming more specialised, and each was developing its own vocabulary of technical terms. One consequence was that it was more difficult for writers to be knowledgeable on the latest thinking across a full range of the sciences. This might not matter in books for five-year olds, but it would in books for teenagers. Another issue arising was that science books went out of date more quickly: there 
Aileen Fyfe, "Tracts, classics and brands: science for children in the nineteenth century" in Popular Children's Literature in Britain, 1700-1900, edited by Julia Briggs, Denis Butts and M. O. G. Grenby

were new discoveries to be added (such as the discovery of Neptune, and the many tiny 'planets' of the asteroid belt which had to be inserted into astronomy books in the late 1840s and 1850s), and there were also new words to be used for existing knowledge. Fortunately, the demand for popular science books - for adults and children - had produced a horde of writers, making it far easier to get new books on the sciences written than it had been at the start of the century. ${ }^{66}$ The importance attached to children's books may be gauged from the fact that several writers who usually wrote for adults turned their hand, at least occasionally, to children's books; the astronomer Robert S. Ball, for instance, wrote Star-land: Being Talks with Young People About the Wonders of the Heavens (1889).

Although the writings of scientific experts became increasingly secularised over the course of the nineteenth century, popular writings - for children and adults generally continued to work within a religious framework. ${ }^{67}$ The way in which religion was introduced, however, became more subtle, as in Margaret Gatty’s Parables from Nature (1855). ${ }^{68}$ For older children, it might even be acceptable to limit the discussion of religion to the preface, as happened in the Rev. John George Wood's Boy's Own Book of Natural History (1861), and Mary and Elizabeth Kirby's Stories About Birds of Land and Water (1873). Nevertheless, while fears of secular science bringing down the establishment had diminished, parents clearly remained concerned for the eternal future of their children. Religious publishing organisations, including the Religious Tract Society and the Society for Promoting Christian Knowledge, continued to produce children's books on a wide range of subjects, 
Aileen Fyfe, "Tracts, classics and brands: science for children in the nineteenth century" in Popular Children's Literature in Britain, 1700-1900, edited by Julia Briggs, Denis Butts and M. O. G. Grenby

including the sciences, and had solid support from parents and schools. The imprints of these organisations offered guardians a guarantee of safe, trustworthy knowledge, at a time when the literary marketplace was expanding, and it was virtually impossible to check the religious credentials of all the writers of books on the sciences. Their success, like that of Gatty's five series of Parables from Nature, shows that religion was far from dead in children's science books.

It is much easier to find evidence about publishers than about actual readers. Publishers' catalogues and archives reveal a great deal about the works which were intended to reach wide audiences, and sometimes provides the opportunity for quantitative comparisons about the total numbers of sales. We do not have that quantitative element for the RTS works, yet from their format and from the Society's typical mode of operation, we can be sure that some of those works reached audiences in the tens of thousands. The works which were printed and reprinted - the classics and the brands - also tell us a great deal about the sorts of projects which publishers were willing to take on, and which they thought would sell. Here, we have a different idea of 'popular', being the works which publishers themselves wanted to reprint or imitate.

It is much more difficult to move from this sort of analysis to a discussion of actual child readers. The fact that publishers kept reprinting implies that someone was buying all these copies, but we have to assume that these were adults. Extrapolating from there to the experiences of their children is difficult, but we may learn something 
Aileen Fyfe, "Tracts, classics and brands: science for children in the nineteenth century" in Popular Children's Literature in Britain, 1700-1900, edited by Julia Briggs, Denis Butts and M. O. G. Grenby

about their own experiences as children, twenty or thirty years earlier, although we must remember that their recollections may have become rose-tinted over the years, and that their choices may be more about what they think their children ought to read, than what they might enjoy. Without more evidence from childhood letters or diaries, it is extremely difficult to decide whether Thackeray was right to claim that children's science books were regarded as hateful medicine. We can, however, be sure that some of them were very widely read.

${ }^{1}$ Parts of this essay originally appeared in my introduction to the 'Science for Children' set of reprints, issued by Thoemmes Press in 2003.

2 'On some illustrated children's books', 1846, quoted in Marjorie Moon, John Harris's Books for Youth 1801-1843: a checklist, Folkestone: Dawson, 1992, revised edn, p. 182.

${ }^{3}$ Charles Kingsley, Madam How and Lady Why, London: Bell \& Daldy, 1870, pp. viii-ix.

${ }^{4}$ Kingsley, Madam How, p. ix.

${ }^{5}$ John Ruskin, The Works of John Ruskin on CD-ROM, Cambridge: Cambridge University Press, 1996, vol. 26, p. 114; Jane Loudon, Glimpses of Nature, and objects of interest described, during a visit to the Isle of Wight, London: Grant \& Griffith, 1844, p. vi; Dennis R Dean, Gideon Mantell and the discovery of the dinosaurs, Cambridge: Cambridge University Press, p. 19; Mrs Lankester, 'For the Young of the Household: In Cozy Nook: Eyes and No Eyes', St. James's Magazine 2 (1861), 121-7; Frederick Maurice, The Life of Frederick Denison Maurice, chiefly told in his own 
Aileen Fyfe, "Tracts, classics and brands: science for children in the nineteenth century" in Popular Children's Literature in Britain, 1700-1900, edited by Julia Briggs, Denis Butts and M. O. G. Grenby

letters, 2 vols., London: Macmillan, 1884, vol. i, p. 16; Richard D Altick, The English Common Reader; a social history of the mass reading public, 1800-1900, London: University of Chicago Press, 1957, pp. 117-18. I would like to thank Anne Secord, Jim Secord and Bernie Lightman for these references.

${ }^{6}$ There is a list of the stories written by Barbauld in Lucy Aikin (ed.) The Works of Anna Laetitia Barbauld, with a memoir, 2 vols., London: Longman, 1825, note to pp. xxxvi-xxxvii.

${ }^{7}$ John Aikin, and Anna Laetitia Barbauld, Evenings at Home; or the Juvenile Budget opened: consisting of a variety of miscellaneous pieces for the instruction and amusement of youth, 6 vols., London: Johnson, rpt. 6 in 2 vols., Bristol: Thoemmes Press, 2003, vol. iv, p. 112.

${ }^{8}$ On the meanings of 'popular', see Morag Shiach, Discourse on Popular Culture: class, gender and history in cultural analysis, 1730 to the present, Cambridge: Polity Press, 1989, 'Introduction' and ch. 3; on the meanings of 'the people', see Patrick Joyce, Visions of the People: industrial England and the question of class, 1848-1918, Cambridge: Cambridge University Press, 1991, 'Introduction'.

${ }^{9}$ Larry Stewart, The Rise of Public Science: rhetoric, technology and natural philosophy in Newtonian Britain, 1660-1750, Cambridge: Cambridge University Press, 1992; Jan Golinski, Science as public culture: chemistry and Enlightenment in Britain, 1760-1820, Cambridge: Cambridge University Press, 1992. 
Aileen Fyfe, "Tracts, classics and brands: science for children in the nineteenth century" in Popular Children's Literature in Britain, 1700-1900, edited by Julia Briggs, Denis Butts and M. O. G. Grenby

${ }^{10}$ J.H. Plumb, 'The new world of children', in N. McKendrick, J. Brewer and J.H. Plumb (eds.), The Birth of a Consumer Society: the commercialization of eighteenthcentury England, Bloomington, Indiana: Indiana University Press, 1982, 286-315.

${ }^{11}$ On Telescope, see James A. Secord, 'Newton in the nursery: Tom Telescope and the philosophy of tops and balls, 1761-1838', History of Science (1985), 23, 127-51. On Newbery, see F.J. Harvey Darton, Children's Books in England: five centuries of social life, 3rd edn. rev. Brian Alderson, Cambridge: Cambridge University Press, 1982, ch. 8 .

${ }^{12}$ Darton, Children's books in England, ch. 10; M. V. Jackson, Engines of Instruction, Mischief and Magic: children's literature in England from its beginnings to 1839, Aldershot: Scolar Press, 1989; Alan Richardson, Literature, Education, and Romanticism: reading as social practice, 1780-1832, Cambridge: Cambridge University Press, 1994; Aileen Fyfe, 'Young Readers and the Sciences', in Marina Frasca-Spada and Nicholas Jardine (eds.), Books and the Sciences in History, Cambridge: Cambridge University Press, 2000, 276-90.

${ }^{13}$ Ann B Shteir, Cultivating Women, Cultivating Science: Flora's daughters and botany in England 1760-1860, London: Johns Hopkins University Press, 1996, ch. 4. ${ }^{14}$ These figures are based on searches of the Nineteenth-Century Short Title Catalogue, series I-III on CD-ROM (NSTC), Newcaste: Avero Publications, 19962002. I have followed the methodology set out in Simon Eliot's 'Patterns and Trends and the NSTC: some initial observations, Part I', Publishing History 42 (1997), 79104. The same caveats apply. These figures are estimated from results for searches 
Aileen Fyfe, "Tracts, classics and brands: science for children in the nineteenth century" in Popular Children's Literature in Britain, 1700-1900, edited by Julia Briggs, Denis Butts and M. O. G. Grenby

combining Dewey class 500 ('pure science') with titles containing 'youth', 'young', 'child' and 'children', and for a search combining Dewey class 500 with class 828.3 ('children's literature'). The resulting sets overlap but not as much as might have been expected, so my figures are merely estimates. The growth of children's science books was actually less rapid than that of science books in general. According to Eliot, the output of works of science almost quintupled between the first and sixth decades of the century: see Simon Eliot, 'Patterns and Trends and the NSTC: some initial observations, Part II', Publishing History, 43 (1998), 71-112.

${ }^{15}$ Maria Edgeworth, and Richard Lovell Edgeworth, Essays on Practical Education, 2 vols., London: Hunter, 1815, vol. I, p. v ('Preface'). See also vol. II, p. 471.

16 The second series of Williams's work appeared in 1845.

${ }^{17}$ According to the title page of the edition issued that year.

${ }^{18}$ Aikin and Barbauld, Evenings at Home, vol. v, p. 8.

${ }^{19}$ Greg Myers, 'Science for women and children: the dialogue of popular science in the nineteenth century', in John Christie and Sally Shuttleworth (eds.), Nature Transfigured: science and literature, 1700-1900, Manchester: Manchester University Press, 1989, 171-200, p. 179.

${ }^{20}$ On the representation of children, see Darton, Children's books in England, p. 220; Anne Scott MacLeod, 'From Rational to Romantic: the children of children's literature in the nineteenth century', Poetics Today, 13 (1992), 141-53.

${ }^{21}$ Priscilla Wakefield, Mental Improvement: or, the beauties and wonders of nature and art, London, 1794-97, rpt. East Lancing, MI, 1995, p. 58. 
Aileen Fyfe, "Tracts, classics and brands: science for children in the nineteenth century" in Popular Children's Literature in Britain, 1700-1900, edited by Julia Briggs, Denis Butts and M. O. G. Grenby (Aldershot: Ashgate, 2008), 209-228.

${ }^{22}$ On religion in Trimmer's An Easy Introduction, see Aileen Fyfe, 'Reading children's books in eighteenth-century dissenting families', Historical Journal, 43 (2000), 453 74.

${ }^{23}$ The classic exposition is Adrian Desmond, 'Artisan resistance and evolution in Britain 1819-1848', Osiris, n.s. 3 (1987), 72-110. See also Colin A Russell, Science and Social Change, 1700-1900, London: Macmillan, 1983, ch. 8.

${ }^{24}$ The various meanings of 'popular' are discussed in Mrs. Percy Sinnett, 'What is popular literature?' The People's Journal, 5 (1848), 7-8, p. 7, and, more recently, in Shiach, Discourse, op. cit., 'Introduction'.

${ }^{25}$ See, for instance, the usage of 'popular' in 'New and cheap forms of popular literature', Eclectic Review, 22 (1845), 74-84 and [Coventry Patmore], 'Popular Serial Literature', North British Review, 7 (1847), 110-36. See also Victor E. Neuburg, Popular Literature: a history and a guide, Harmondsworth: Penguin, 1977.

${ }^{26}$ Price for the 1806 edition of Marcet, 2 vols., $12 \mathrm{mo}$ and for the 1809 edition of Joyce, 6 vols., 18mo. See entries in Sampson Low (ed.) The English Catalogue of Books, London: Low, 1864-1914.

${ }^{27}$ On the history of the RTS, see William Jones, The Jubilee Memorial of the Religious Tract Society: containing a record of its origin, proceedings, and results. $A D 1799$ to AD 1849, London: RTS, 1850; Samuel G Green, The Story of the Religious Tract Society for One Hundred Years, London: RTS, 1899. On the RTS and children's books, see Brian Alderson's 'Appendix I' to Darton, Children's books in England, pp.317-18. Also, Brian Alderson, and Pat Garrett (eds.), The Religious Tract 
Aileen Fyfe, "Tracts, classics and brands: science for children in the nineteenth century" in Popular Children's Literature in Britain, 1700-1900, edited by Julia Briggs, Denis Butts and M. O. G. Grenby

Society as a publisher of children's books: catalogue of an exhibition prepared to celebrate the 200th anniversary of the foundation of the RTS presented at a conference at the University of East Anglia, Norwich, 28 July to 1 August 1999, Hoddesdon: Children's Book History Society, 1999.

${ }^{28}$ Catalogue C, appended to RTS Annual Report (1850). RTS works were typically undated, and frequently anonymous. The publications dates and authors' names in the following discussion have been identified from marginalia on the Society's archive copies of its monthly publications lists (RTS/USCL archives, School of Oriental and African Studies, London). I am currently compiling a check-list of publications from these lists, which cover the years 1842-59.

${ }^{29}$ [Charles Williams], Uncle William's Talkings with Children about Plants, London: RTS, 1846, 'The hazel-nut', pp. 1-16; 'The nettle', pp. 6-7 (numbering restarts for each section).

${ }^{30}$ [Charles Williams], Wonders of the Waters, London: RTS, 1842, rpt. Bristol:

Thoemmes Press, 2003, pp. 99-100.

${ }^{31}$ [Williams], Wonders of the Waters, p. 147.

${ }^{32}$ See Aileen Fyfe, 'Industrialised Conversion: the Religious Tract Society and the development of popular science publishing in Victorian Britain', unpublished Ph.D., University of Cambridge, 2000, pp. 46 and 49.

${ }^{33}$ After Williams's departure, the editorship was divided between two people, one as General Editor, one as Children's editor. Fyfe, 'Industrialised Conversion', pp. 46-51. ${ }^{34}$ The first reference to Kronheim that I noted in the RTS archives was from 1854. 
Aileen Fyfe, "Tracts, classics and brands: science for children in the nineteenth century" in Popular Children's Literature in Britain, 1700-1900, edited by Julia Briggs, Denis Butts and M. O. G. Grenby

${ }^{35}$ Some of Eliza Payne's addresses are given in the RTS archives which makes it possible to identify the family in those Census returns which have been computerised. They reveal that she was probably born c.1815 and that Alfred was a widower by 1881. Her last book was published in 1872. My thanks to Morag Fyfe for assistance with the census returns.

${ }^{36}$ [Eliza W Payne], Peeps at Nature: or, God's Works and Man's Wants, London: RTS, 1850, p. [3].

${ }^{37}$ [Payne], Peeps at nature, p. 27.

${ }^{38}$ Jones, Jubilee memorial, 'Appendix V'.

${ }^{39}$ T. S. Eliot, What is a classic?, London: Faber, 1944; Frank Kermode, The Classic, London: Faber, 1975; Italo Calvino, Why Read the Classics? (tr. Martin McLaughlin), London,: Jonathan Cape, 1999. My discussion of the role of publishers in creating classics is to be found in Aileen Fyfe, 'Publishing and the Classics: Paley's Natural Theology and the nineteenth-century scientific canon', Studies in History and Philosophy of the Sciences 33 (2002), 733-55.

${ }^{40}$ On bestsellers, see the list appended to Altick, English common reader, and the follow-ups, Richard D Altick, 'Nineteenth-century bestsellers: a further list', Studies in Bibliography 22 (1969), 197-206 and 'Nineteenth-century bestsellers: a third list', Studies in Bibliography, 39 (1986), 235-41.

${ }^{41}$ On the Parleys, see Darton, Children's books in England, pp. 221-8. On Samuel Clark, and the natural history he wrote as Peter Parley, see James A Secord's 
Aileen Fyfe, "Tracts, classics and brands: science for children in the nineteenth century" in Popular Children's Literature in Britain, 1700-1900, edited by Julia Briggs, Denis Butts and M. O. G. Grenby

'Introduction' to Samuel Clark, Peter Parley's Wonders of the Earth, Sea and Sky 1837, rpt. Bristol: Thoemmes Press, 2003.

${ }^{42}$ Edgeworth, and Edgeworth, Practical Education, vol. I, pp. 434-5.

${ }^{43}$ Sarah Trimmer, 'Review of Evenings at Home', Guardian of Education 2 (1803), 304-11, 43-53, 353.

${ }^{44}$ Evidence for reading is discussed in Fyfe, 'Reading children's books'.

${ }^{45}$ On these and other revisions, see Aileen Fyfe, 'How the squirrel became a squgg: the long history of a children's book', Paradigm, 27 (1999), 25-37.

${ }^{46}$ Longman Archives, H10 214; H12 221. The Longman Archives are held at the University of Reading Library, and are also available on microfilm from ChadwyckHealey. The guide to the microfilm edition is Alison Ingram (ed.) Index to the Archives of the House of Longman, 1794-1914, Cambridge: Chadwyck-Healey, 1981.

${ }^{47} 1846$ sales figures are from Longman Archive, H1 11.

${ }^{48}$ The full publishing history is discussed in Aileen Fyfe, 'Copyrights and Competition: producing and protecting children's books in the nineteenth century', Publishing History 45 (1999), 35-59.

${ }^{49}$ F. A. Mumby, The House of Routledge, 1834-1934, with a history of Kegan Paul, Trench, Trubner and other associated firms, London: Routledge, 1934. See also the 'Routledge' entry in Patricia J Anderson, and Jonathan Rose, British Literary Publishing Houses, 1820-1880, Detroit: Gale Research, 1991.

${ }^{50}$ Routledge Publication Book (1850-58), 1-3. The Routledge Archive is kept at University College London, and is described in Gillian Furlong, Handlist to the 
Aileen Fyfe, "Tracts, classics and brands: science for children in the nineteenth century" in Popular Children's Literature in Britain, 1700-1900, edited by Julia Briggs, Denis Butts and M. O. G. Grenby

Archives of George Routledge \& Co., 1853-1973, London: University College

London Library, 1973.

${ }^{51}$ On the revisions, see Fyfe, 'Squirrel'.

${ }^{52}$ Longman Archive, H14 20.

${ }^{53}$ Routledge Publication Book 1 (1850-58), 211 (1855-58) and 645 (1858-81).

Longman Archive H15 3; H1 11.

${ }^{54}$ Routledge Publication Book 391 (1866-84), 254 (1881-89) and 386 (1889-1902).

55 The first share-holder edition to be illustrated appears to be that of 1846 .

${ }^{56}$ Priscilla Wakefield, Mental Improvement: or, the beauties and wonders of nature and art, 1797; rpt. East Lancing, MI, 1995.

${ }^{57}$ Results of searching NSTC title index for 1800-20.

${ }^{58}$ On Marcet and her Chemistry, see M. Susan Lindee, 'The American career of Jane Marcet's Conversations on Chemistry, 1806-1853', Isis 82 (1991), 8-23, Greg Myers, 'Fictionality, demonstration, and a forum for popular science: Jane Marcet's Conversations on Chemistry', in Barbara T. Gates and Ann B. Shteir (eds.), Natural Eloquence: women reinscribe science, Madison WI: University of Wisconsin Press, 1997, pp. 43-60.

${ }^{59}$ Longman Archive, A1 285; A2 87-8, 105; A3 87, 285, 289.

${ }^{60}$ Greg Myers refers to the political economy work as being very widely read, Myers, 'Fictionality and demonstration', p. 43.

${ }^{61}$ See the listing for the title 'Conversations...' in the relevant volume of Low (ed.), The English Catalogue of Books. 
Aileen Fyfe, "Tracts, classics and brands: science for children in the nineteenth century" in Popular Children's Literature in Britain, 1700-1900, edited by Julia Briggs, Denis Butts and M. O. G. Grenby (Aldershot: Ashgate, 2008), 209-228.

${ }^{62}$ Longman division ledgers, A1 285; A1 285; A4 63; and A4 65. Longman Archives.

${ }^{63}$ This also fits with the fact that much of the surviving evidence of reading for Evenings at Home comes from accounts of those who were children in the 1820 s.

${ }^{64}$ The last edition appears to be from 1868.

${ }^{65}$ On technological developments, see Philip Gaskell, A New Introduction to

Bibliography, Oxford: Clarendon, 1972; Michael Twyman, Printing 1770-1970: an illustrated history of its development and uses in England, London: British Library, 1999.

${ }^{66}$ On late nineteenth-century popular science, see Bernard Lightman, '"The Voices of Nature": popularising Victorian science', in Bernard Lightman (ed.), Victorian science in context, Chicago: University of Chicago Press, 1997, pp. 187-211; Bernard

Lightman, 'The Story of Nature: Victorian popularizers and scientific narrative', Victorian Review 25 (1999), 1-29; Bernard Lightman, 'The visual theology of Victorian popularizers of science: from reverent eye to chemical retina', Isis, 91 (2000), 651-80.

${ }^{67}$ On religion in adult works, see Lightman, 'Visual theology'.

${ }^{68}$ Suzanne LeMay-Sheffield, 'Introduction' to Margaret Gatty, Parables from Nature, London: Bell, 1855, rpt. Bristol: Thoemmes Press, 2003. 